CLINICAL HEMORHEOLOGY, Vo1. 5, pp. 1-4, 1985

$0271-5198 / 85 \$ 3.00+.00$ Printed in the USA.

Copyright (c) 1985 Pergamon Press Ltd. All rights reserved.

\title{
FOREWORD and EDITORIAL
}

The Third European Conference on Clinical Hemorheology took place in Baden-Baden, F.R. Germany, 24-27 August 1983. Its first day was a session jointly held on the last day of the Fifth International Congress of Biorheology, 20-24 August 1983, taking place at the same site, the Congress House, in Baden-Baden under the auspices of the Albert-Ludwig Universität Freiburg im Breisgau, F. R. Germany. The Proceedings of the Fifth International Congress of Biorheology and of the Third European Conference on Clinical Hemorheology have been published in the official journals of the International society of Biorheology, viz. BIORHEOLOGY and its Companion Journal CLINICAL HEMORHEOLOGY. The Proceedings of these meetings published in CLINICAL HEMORHEOLOGY were mainly edited by A.L. Copley and H. Schmid-Schönbein, while the communications published in BIORHEOLOGY were edited by A.L. Copley and S. Witte.

It is the policy of both journals to publish communications pertaining to (a) all fields of biorheology with the exception of clinical hemorheology in BIORHEOLOGY and (b) clinical hemorheology in CLINICAL HEMORHEOLOGY. Thus, communications dealing with theoretical and experimental hemorheology appear in BIORHEOLOGY. We recommend to our Readers, interested in theoretical and experimental hemorheology, to acquaint themselves with communications in these fields as published in BIORHEOLOGY for the reasons stated above. Communications of the Third European Conference on Clinical Hemorheology have been published in issues of both Journals.

The Conference Abstracts appeared in CLINICAL HEMORHEOLOGY, $3(3), 215-348,1983$. The Plenary Lectures and the symposia containing the invited papers regarding the Conference were published as follows: Part I - CLINICAL HEMORHEOLOGY 4(2/3), 101-361, 1984; Part II - BIORHEOLOGY 21(4), 559-659, 1984 as "Alexander 
Naumann Memorial Symposium on 'Rheology and Atherogenesis'" (R.M. Nerem and D. Liepsch, Eds.)

This special issue of CLINICAL HEMORHEOLOGY constitutes Part III of the Conference Proceedings and is limited to the Symposium entitled "Rheological Aspects of Plasmapheresis." Its Guest Editors are E.F. Leonard and H.G. Sieberth. Holger SchmidSchönbein, Chairman of the Organizing Committee of the Conference, is the author of the Preface.

The above Conference Proceedings do not include free communications or texts dealing with poster presentations. As these Conference Communications are not invited, their authors are free to submit them to CLINICAL HEMORHEOLOGY to an Editor of their choice in accordance with our editorial policy given under Instructions to Authors appearing in each issue. Such Conference Communications have appeared thus far in CLINICAL HEMORHEOLOGY, $\underline{4}(5), 495-$ 512,1984 .

Some of the Symposium Papers have not been technically presented in strict adherence to our Instructions to Authors. Nevertheless, we have chosen to accept these Papers in order not to delay their publication in this special Issue.

The Symposium: "Hemorheological Disorders in Cardiovascular Diseases" (B.E. Strauer, Ed.) constitutes Part II of the Proceedings of the Fifth International Congress of Biorheology. It has been published as a special issue of CLINICAL HEMORHEOLOGY, $4(1)$, $1-86,1984$.

Our Readers are directed to other communications regarding clinical hemorheology that were presented at the Fifth International Congress of Biorheology at its Satellite Meeting, held in Nancy, France 17-18 August 1983. The Proceedings of this International Symposium, entitled "New Methods in Biorheology," (J.F. Stoltz and E. Puchelle, Eds.) were published as supplement I of BIORHEOLOGY in 1984 and comprises 354 pages.

Those Readers interested in theoretical and experimental hemorheology will find the Communications in these fields presented 
at the Congress, as follows: BIORHEOLOGY $\underline{21}(1 / 2), 1-223,1984 ; \underline{21}$ (4), 419-659, 1984. Of particular interest to the Readers of CLINICAL HEMORHEOLOGY is the Congress Symposium on "Permeability and the Blood Vessel Wall," (A. Silberberg, Ed.), BIORHEOLOGY 21(1/2), $105-223,1984$.

The Proceedings of the First European Conference on Clinical Hemorheology, held at Nancy, France, 17-19 October 1979, were edited by J.F. Stoltz and P. Drouin and published by Doin, Paris, France in 1980 (709 pp.). The Proceedings of the second European Conference on Clinical Hemorheology, edited by A.L. Copley and J. Dormandy, held under the auspices of the Royal Society of Medicine, London, appeared in CLINICAL HEMORHEOLOGY 1(5/6), 407-526, 1981 and $2(4), 295-381,1982$. Communications on clinical hemorheology presented at the Fourth International Congress of Biorheology, Tokyo, Japan, 27 July - 1 August 1981, entitled "Recent Advances in Clinical Hemorheology" (Y. Isogai, Ed.) were published in CLINICAL HEMORHEOLOGY, 2(4), 259-294, 1982. Papers presented at the Satellite Meeting of the International Congress of Biorheology, Osaka, Japan, 3 August 1981, entitled "Hemorheological Approaches to Cardiovascular Diseases" (H. Niimi, T. Azuma, Y. Isogai, Eds.) appeared in a special issue of CLINICAL HEMORHEOLOGY, $\underline{2}(1 / 2)$ 1-173, 1982. We recommend to our Readers the Proceedings of all three European Conference on Clinical Hemorheology as well as the Congress Proceedings pertaining to clinical hemorheology, published in both CLINICAL HEMORHEOLOGY and in BIORHEOLOGY.

The Fourth European Conference on Clinical Hemorheology will take place in Siena, Italy, 20-22 June 1985 under the chairmanship of T. Diperri, who is one of our Editors. Of interest to our Readers will also be the Sixth International Congress of Biorheology, to be held in Vancouver, Canada 13-19 July 1986, under the chairmanship of $D$. Brooks. Information concerning these two International Meetings will be published in forthcoming issues of CLINICAL HEMORHEOLOGY and BIORHEOLOGY.

The details, presented above, are meant as a guide to the present status of clinical hemorheology. Hemorheology continues to be the most vigorous branch of the science of biorheology. As 
clinical hemorheology, it has become indispensable for the practice of medicine and surgery.

We are confident that our Readers will welcome this special Issue on Plasmapheresis as a fine contribution to CLINICAL HEMORHEOLOGY. With this issue, we celebrate the beginning of the fifth year of our Journal and we extend our Best Wishes for the New Year to our Editors, Authors, and Readers.

Alfred L. Copley and Siegfried Witte Editors-in-Chief 